\title{
Proteolytic enzymes in the marine bacterium Pseudoalteromonas atlantica: post-secretional activation and effects of environmental conditions
}

\author{
Monica Hoffman, Alan W. Decho* \\ Department of Environmental Health Sciences, School of Public Health, University of South Carolina, Columbia, \\ South Carolina 29208, USA
}

\begin{abstract}
Production and activities of cellular and extracellular proteolytic enzymes associated with the marine bacterium Pseudoalteromonas atlantica were examined in response to physiological state and changing environmental variables under laboratory conditions. Enzymes evidenced by zymography were metalloproteases, as defined by substrate preference and susceptibility to inhibitors (EDTA and 1,10-phenanthroline). Distinct bands (i.e., molecular-weight [MW] size classes) of enzymes were isolated from within cellular and extracellular compartments. Susceptibility of extracellular enzymes to environmental stressors was related, in part, to the MW size classes of the enzymes. While all bands of enzymes showed some degree of inhibition when $\mathrm{pH}$ was decreased, the very high MW (103 to $93 \mathrm{kDa}$ ) and the very low MW (34 to $31 \mathrm{kDa}$ ) bands of extracellular enzymes were most susceptible. Some mid-sized enzymes ( 75 to $69 \mathrm{kDa}$ ) were most resilient, and remained active at $\mathrm{pH}$ as low as 4.4 and as high as 10.5 - values which may occur in seawater micro-environments during high levels of heterotrophic respiration and photosynthetic activities, respectively. Extracellular enzymes retained activity in seawater (25 ppt) as long as $15 \mathrm{~d}$ after secretion. Finally, our data strongly suggest that extracellular enzymes, which were recently secreted by cells, may be modified post-secretion, as evidenced by changes in MW banding patterns over time (in presence of chloramphenicol). This study showed that $P$. atlantica produces a flexible array of extracellular enzymes. In ocean systems the adaptive value of flexibility in enzyme activities may relate to changing microenvironments which bacteria may encounter over microspatial scales.
\end{abstract}

KEY WORDS: Proteolytic enzymes $\cdot$ Activation $\cdot$ Stability $\cdot$ Bacteria $\cdot$ Environmental conditions

\section{INTRODUCTION}

The uptake of most nutrients by heterotrophic bacteria depends on osmotrophy, a nutritional strategy in which soluble nutrients are absorbed through the cell surface (Singleton \& Sainsbury 1987). The outer membrane of Gram-negative bacteria acts as a molecular sieve. The nature of the amino acid residues is the major factor that determines the hydrodynamic volume of a protein or peptone, which in turn discriminates between which molecules are fit for uptake (Payne \&

*Corresponding author. E-mail: adecho@sph.sc.edu
Gilvarg 1968). Therefore, only relatively small molecules can be readily transported across the bacterial membrane. Studies using mutant bacterial strains (no longer capable of synthesizing individual amino acids) (Gilvarg \& Katchalski 1965) and gel filtration techniques (Payne \& Gilvarg 1968) suggested that the cutoff point was between 4 and 6 amino acids (Cascieri \& Mallette 1976), or around 650 Da (Payne 1980).

It has been estimated that 65 to $80 \%$ of dissolved organic matter (DOM) in ocean surface waters consists of low molecular-weight molecules (below 1000 Da), yet larger molecules seem to have higher nutritional potential. Studies of bacterial utilization of natural DOM pools have shown higher growth and respiration 
rates when cells were exposed to high molecular weight DOM, than in the presence of low molecular fractions (Amon \& Benner 1994, Skoog et al. 1999). Bacteria secrete enzymes that allow them to hydrolyze high molecular-weight species outside the cells, prior to uptake. Such compounds may be present either in dissolved form, or as particulate organic matter (POM). POM in oceans includes marine snow (or water-column aggregates), which consists of phytoplankton, detritus, bacteria and fecal pellets, embedded in a mucous matrix (Alldredge \& Cohen 1987). Bacteria associated with marine snow display higher levels of hydrolytic activities that recycle organic matter from particulate into dissolved phase (Wetzel 1991, Smith et al. 1992). Herndl (1988) examined depth profiles of marine snow in the Adriatic Sea and found that while the size of the aggregates increased, their organic content decreased with depth. This trend was attributed to bacterial decomposition and biotransformation of aggregate organic matter, as well as entrapment of resuspended inorganic material. Therefore, bacterial processing of organic matter, especially high molecular fractions, which requires cellular and extracellular enzymatic hydrolysis, is an important biotransformation process of organic matter in oceans.

Bacterial proteolytic enzymes are generally classified according to 3 criteria: location with respect to the cell, site of proteolytic attack and structural similarities. Three classes of enzymes are generated based on the location of the enzymes: 'extracellular enzymes' (those that occur 'free', dissolved in water, or attached to surfaces other than the cell that produced them), 'ectoenzymes' (secreted enzymes that actively cross the cytoplasmic membrane and remain associated with the producing cell; this definition also includes the periplasmic enzymes) and 'intracellular' enzymes (enzymes that are synthesized, located and act upon substrates within the cytoplasm) (Chróst 1991). For the purpose of the present paper the ectoenzymes and intracellular enzymes will be collectively referred to as 'cellular' enzymes.

The processing and hydrolysis of high molecularweight DOC (by extracellular enzymes) and subsequent utilization of hydrolysis products by bacteria can only be efficient if both enzymes and products are localized close to cells. Enzymes, as well as the products of degradation that they generate, can be modified by chemical or physical factors present in the environment. Also, extracellular enzymes and hydrolysis products can be lost by diffusion into the surrounding water. However, Engasser \& Horvath $(1974 a, b)$ found that the concentrations of substrates at cell surface are lower than in the surrounding waters, due to boundary-layer effects. Thus, the probability of enzymes attached to the cell surface to encounter a substrate molecule is less, compared to the enzymes in the immediate vicinity of cells. It was estimated that as long as substrate molecules are present within a $500 \mu \mathrm{m}$ radius, the energy balance favors the release of enzymes and the extracellular degradation of the substrate (Wetzel 1991).

In natural systems, parameters such as nutrients, temperature, $\mathrm{pH}$, and oxygen level fluctuate widely and often become sources of stress for bacteria. Azam \& Amerman (1984) introduced the concept of a structured nutrient field, defined as 'a region in which there are sharp gradients of bacterial nutrients'. The structure of such microdomains is subjected to changes driven by biological processes (such as uptake of nutrients), as well as physical processes (e.g., molecular diffusion, micro-turbulence). Various degrees of starvation are the normal state for wild-type microorganisms, while short bursts of nutrient excess represent exceptions. It is to be expected, therefore, that bacterial communities may develop a range of adaptive mechanisms to cope with the changing environment (Morita 1985). As a result, natural communities exist in a range of physiological states. One short-term response of cells to starvation is the process of dwarfing, which occurs in 2 phases. During the first phase, fragmentation generates increasing numbers of spheroids. Throughout the second phase the spheroids undergo continuous size reduction under constant cell density (Kjelleberg et al. 1983). Longer-term responses include induction of a vegetative state that requires minimal energy expenditure, primarily for the maintenance of the membrane potential. It was suggested that in such cases endogenous metabolism should suffice to provide the energy (Dawes 1985). Microorganisms that can readily utilize a variety of polymeric substrates resume synthesis of cellular components, based on the uptake of degradation fragments (Chróst 1990). In either case, persistence of proteolytic enzymes in the surrounding waters, in close proximity to the cells, is crucial.

Pseudoalteromonas (previously Alteromonas) is a marine bacterium, which has the capacity to grow as both free-living (planktonic) cells and as attached biofilm to surfaces (Corpe 1970, Decho \& Lopez 1993) and adapt to wide ranges of temperature $\left(10\right.$ to $\left.30^{\circ} \mathrm{C}\right)$, salinity (10 to $30 \mathrm{ppt}$ ), and nutrient regimes (Decho unpubl. data).

The purpose of this study was to identify and characterize the proteolytic enzymes produced by Pseudoalteromonas atlantica, and the influence of various environmental factors on the enzymatic activity. Though traditionally the marine environment has been perceived as a relatively continuous and constant system, the effect of environmental factors on microbial metabolism in marine systems has attracted recent interest 
because of the microscale nutrient patchiness concept (Herndl 1988, Azam 1998, Blackburn et al. 1998).

Specifically, the following questions were addressed: (1) Is Pseudoalteromonas atlantica synthesizing enzymes capable of degrading larger forms of DOM?; (2) What classes of enzymes are produced by $P$. atlantica?; (3) Where are the enzymes located, relative to the cells?; and (4) What is the fate of the secreted enzymes and how do environmental factors (such as divalent cations, $\mathrm{pH}$, temperature, nutrient availability) affect the activities of enzymes?

\section{MATERIALS AND METHODS}

Bacterial strain and culture conditions. Pseudoalteromonas (formerly Alteromonas) atlantica (ATCC No. 43666) was purchased from the American Type Cell Culture (Rockville, MD, USA). Bacteria were grown in modified half-strength D-glucose-Peptone medium (ATCC \#268). Medium composition was D-glucose $10 \mathrm{~g} \mathrm{l}^{-1}$, Bacto-Peptone $5 \mathrm{~g} \mathrm{l}^{-1}$, in $25 \mathrm{ppt}$ sterile-filtered Gulf Stream seawater (Sigma Chemicals). After adjusting the $\mathrm{pH}$ to 8.0 , the medium was filtered $(0.2 \mu \mathrm{m})$ and autoclaved.

Bacteria ( $24 \mathrm{~h}$ cultures, $A_{600}=1.0$ absorption units) were inoculated in duplicate in $250 \mathrm{ml}$ flasks containing $125 \mathrm{ml}$ sterile medium. Cultures were grown at $24^{\circ} \mathrm{C}$ on a shaker table at $100 \mathrm{rpm}$. Depending on the experiments, the cells were allowed to grow for varying lengths of time. The $A_{600}$ was monitored on a Shimadzu UV/Vis spectrophotometer (model UV-2401PC) as an indicator of cell density/physiological state. Absorption values were recorded each time aliquots were removed.

Extraction of extracellular and cellular enzymes. The following experiment was designed to identify and compare the cellular and the extracellular enzymes. Stationary phase cultures were used to generate banding patterns of maximum complexity. Cultures were centrifuged $\left(17000 \times g\right.$, at $4^{\circ} \mathrm{C}$, for $\left.30 \mathrm{~min}\right)$ in sterile Oak Ridge centrifuge tubes. Supernatants were transferred to sterile Oak Ridge centrifuge tubes and centrifuged $\left(27000 \times g\right.$, at $4^{\circ} \mathrm{C}$, for $\left.30 \mathrm{~min}\right)$. One $\mathrm{ml}$ fractions were transferred to sterile microfuge tubes, with care taken not to disturb the cell pellet. These fractions (containing the extracellular enzymes) and all aliquots used in this study were frozen to $-70^{\circ} \mathrm{C}$ until subjected to electrophoresis.

A modification of the protocol followed by Albertson et al. (1990) was used to isolate cellular enzymes. All procedures were carried out at $4^{\circ} \mathrm{C}$ (or on ice). Cell pellet fractions that resulted from the separation of extracellular enzymes were resuspended in fresh sterile medium, and centrifuged $\left(17000 \times g\right.$, at $4^{\circ} \mathrm{C}$, for $\left.30 \mathrm{~min}\right)$.
The supernatant was discarded and the new cell pellet resuspended in $1 \mathrm{ml}$ sterile distilled water and placed on ice. After 20 min the cell suspension was centrifuged for $10 \mathrm{~min}$. This procedure created an osmotic shock that produced the lysis of the outer membrane of a Gram-negative bacterium. The lysed cell pellets were temporarily stored at $4^{\circ} \mathrm{C}$, while the supernatant (from here on referred to as lysis supernatant) was sterile filtered through a $0.2 \mu \mathrm{m}$ pore size membrane and stored on ice.

The lysed cell pellets were further used for extraction of intracellular enzymes. Pellets were resuspended in $2 \mathrm{ml}$ of sterile distilled water and disrupted using a sterile glass tissue grinder (Kontes Glass), then filtered through a sterile membrane $(0.2 \mu \mathrm{m}$ pore size). This filtrate and lysis supernatant were combined as the cellular enzyme fraction.

Enzyme activity assay. We used the technique of substrate-incorporated polyacrylamide gel electrophoresis (zymography) to separate and characterize the enzymes produced by cultures of Pseudoalteromonas atlantica, as well as to evaluate the effect of environmental factors on the activity of these enzymes. The composition of the gels $4 \%$ stacking and $10 \%$ resolving) was similar to that used by Laemmli (1970), except that a substrate (gelatin, casein, or casamino acids) was incorporated in the resolving gel mixture prior to casting (final concentration of $1 \mathrm{mg} \mathrm{ml}^{-1}$ ). Enzyme extracts (10 $\mu$ l) were incubated (at $24 \pm 2^{\circ} \mathrm{C}$, for $20 \mathrm{~min}$ ) with an equal amount of non-reducing sample buffer (Bio Rad Laboratories, Hercules) containing sodium dodecyl sulfate (SDS). SDS was added to estimate the molecular weight of each protease in the absence of reducing agents, which irreversibly decreased the enzymatic activities reported in this study. SDS conferred all proteins a net negative charge. Thus all enzyme molecules present in the sample followed the same direction of migration. Fifteen $\mu \mathrm{l}$ of enzyme incubates and $10 \mu \mathrm{l}$ prestained molecular-weight standards (Bio Rad) were loaded on the gels. Electrophoresis was carried out under constant voltage $(180 \mathrm{~V})$, starting at $40 \mathrm{~mA}$ per gel, in a Mini-Protean II electrophoresis cell (Bio Rad), using a Model 1000/500 Constant Voltage Power Supply (Bio Rad). Constant monitoring was required to prevent the gels from warming up. Gels were rinsed in incubation buffer (50 mM Tris- $\mathrm{HCl}, 5 \mathrm{mM} \mathrm{CaCl}_{2}, 1 \mu \mathrm{M}$ $\mathrm{ZnCl}_{2}$ ), pH 7.5. During the first rinse step, Triton X-100 $(2.5 \%)$ was added to remove SDS from gels, thus allowing the enzymes to refold and return to active configuration. After $20 \mathrm{~min}$ the gels were transferred to fresh incubation buffer for an additional $20 \mathrm{~min}$.

The enzymatic digestion of gelatin was allowed to proceed in fresh incubation buffer, at $30 \pm 1^{\circ} \mathrm{C}$, for $48 \mathrm{~h}$. The gels were briefly rinsed in deionized water to stop the enzymatic reaction and stained with $1 \%(\mathrm{wt} / \mathrm{v})$ 
Coomassie Blue G-250 solution (in 10\% acetic acid in $50 \%$ methanol) for $15 \mathrm{~min}$, under gentle rocking. The stained gels were rinsed in the acetic acid/methanol cocktail for $5 \mathrm{~min}$. The removal of excess stain continued in deionized water until the stacking gel was free of dye.

Enzymes were visualized using a light box (400 to $700 \mathrm{~nm}$ ) as clear bands against a blue background. The Coomassie-stained background did not show signs of discoloration or layering, indicating that the substrate (gelatin) remained incorporated in the polyacrylamide matrix. The gels were recorded on a Kodak Digital Camera (model DC-260). For publication purposes the images were edited using the program Adobe PhotoShop 5.0. For long-term preservation, gels were dried using a Gel Drying Kit (Promega).

Inhibition experiments. To determine what classes of enzymes were produced by Pseudoalteromonas atlantica, $10 \mu \mathrm{l}$ inhibitors of various enzyme classes were added to the enzyme extracts. The inhibitors and their final concentrations are listed in Table 1. Ten $\mu \mathrm{l}$ of each solvent used to dissolve the inhibitors were added to controls and run simultaneously. After electrophoresis, in the case of EDTA (ethylendiaminotetraacetic acid) inhibition experiments, the gels were incubated in $\mathrm{Ca}^{2+} / \mathrm{Zn}$-free Tris-HCl buffer and compared to gels incubated as described above.

Quantitative evaluation of the inhibition of enzyme activity by EDTA was performed using a fluorometric assay. The levels of enzyme activity were measured based on the proteolytic degradation of pig skin gelatin labeled with Oregon Green ${ }^{488}$ (Molecular Probes), reconstituted in incubation buffer. Controls consisted of cell-free enzyme extracts to which gelatin Oregon Green ${ }^{488}$ was added to $0.02 \mathrm{mg} \mathrm{ml}^{-1}$ final concentration. 1,10-phenanthroline and EDTA inhibit the same class of proteases. The magnitude of the inhibitory effect was measured using EDTA, since the solutions were gentler on the fluorescent substrate solutions compared to 1,10-phenanthroline solutions. EDTA to $2.5 \mathrm{mM}$ final concentration was added to inhibition treatments. Two controls and triplicate treatments were used in each experiment. The mean and standard deviation were computed on 4 independent experiments. Both controls and treatments were incubated in the dark, at room temperature, for $20 \mathrm{~h}$. The fluorescence of the samples was measured $\left(\lambda_{\mathrm{ex}} / \lambda_{\mathrm{em}}=\right.$ $488 \mathrm{~nm} / 519 \mathrm{~nm}$ ) at the beginning and end of the incubation period, using a FluoroMax 2 instrument (Jobin Yvon/SPEX).

Effect of physiological state on enzyme activities. The following experiment allowed us to investigated the possibility that as cells change their physiological states (e.g., lag, log, stationary phase) different enzymes may be produced, in response to changing nutrient concentrations.
Cells were grown in batch cultures. One $\mathrm{ml}$ aliquots were removed from duplicate flasks at $8 \mathrm{~h}$ intervals, for the first $24 \mathrm{~h}$, and then every $12 \mathrm{~h}$ until the termination of the experiment. The aliquots were centrifuged at $17000 \times g$, for $30 \mathrm{~min}$. The supernatant was transferred to sterile microfuge tubes, without disturbing the cell pellet, and stored at $-70^{\circ} \mathrm{C}$. We compared the banding pattern at different times and $A_{600}$ values.

Effect of pH on enzyme activities. Experiments were conducted to examine the effect of $\mathrm{pH}$ on individual enzyme activities. Following electrophoresis, the $\mathrm{pH}$ of all buffers was adjusted in the range of 4.4 to 10.2 , using $1.0 \mathrm{pH}$ unit increments. To avoid errors due to electrophoresis, or subsequent manipulations, all gels were run simultaneously. The gels were stained and destained as described above, and observed using a light box. The controls consisted of gels incubated at $\mathrm{pH}$ 7.5. The absence or decreased intensity of a band was considered to be indicative of enzymatic activity inhibition.

Temporal stability of enzymes. To determine how long secreted enzymes remained active in the absence of protein synthesis, we followed the fate of extracellular enzymes for $48 \mathrm{~h}$. A $24 \mathrm{~h}$ Pseudoalteromonas atlantica inoculum was centrifuged at $27000 \times g$, at $4^{\circ} \mathrm{C}$, for $30 \mathrm{~min}$. Chloramphenicol $\left(150 \mathrm{\mu g} \mathrm{ml}^{-1}\right.$ final concentration) was added to the supernatant, to inhibit protein synthesis in case metabolically active cells were still present. The supernatant was transferred to a sterile $250 \mathrm{ml}$ flask and placed on a shaker table. Aliquots were taken before and after addition of chloramphenicol (as controls for baseline and effect of chloramphenicol on enzymatic activities) and at $12 \mathrm{~h}$ intervals, for as long as $48 \mathrm{~h}$. The remaining cell-free medium was observed for $72 \mathrm{~h}$ for cell growth.

Enzyme activities in natural seawater. The purpose of these experiments was to determine if natural seawater could provide proper conditions for enzyme activity development. Aliquots from the same sample

Table 1. Concentrations of protease inhibitors used to determine (on gelatin-incorporated gels) the classes of enzymes produced in Pseudoalteromonas atlantica cultures

\begin{tabular}{|lcl|}
\hline Protease inhibitor & $\begin{array}{c}\text { Final } \\
\text { concentration }\end{array}$ & $\begin{array}{c}\text { Class of protease } \\
\text { inhibited }\end{array}$ \\
\hline EDTA & $50 \mathrm{mM}$ & Metalloproteases \\
1,10 phenanthroline & $10 \mathrm{mM}$ & $\begin{array}{l}\text { Metalloproteases } \\
\text { PMSF }\end{array}$ \\
Antipain & $50 \mu \mathrm{mM}$ & Serine proteases \\
Thimerosal & $5 \mathrm{mM}$ & Serine proteases \\
Pepstatin & $50 \mu \mathrm{g} \mathrm{ml}{ }^{-1}$ & Ahiol proteases \\
Chymostatin & $100 \mu \mathrm{g} \mathrm{ml}{ }^{-1}$ & Chymotrypsin \\
Elastinal & $10 \mu \mathrm{M}$ & Elastase \\
\hline
\end{tabular}


were run simultaneously on 2 separate gels. After electrophoresis, one gel was processed as described. The second gel was rinsed twice in $50 \mathrm{mM}$ Tris- $\mathrm{HCl}_{1} \mathrm{pH}$ 7.5 , with the addition of $2.5 \%$ Triton X-100 to the first rinse. The activity of the enzymes separated on the second buffer was allowed to develop in autoclaved, sterile-filtered Gulf Stream seawater (Sigma), instead of the regular incubation buffer.

\section{RESULTS}

\section{Release of extracellular enzymes in different physiological states}

In all physiological states, supernatants from cultures of Pseudoalteromonas atlantica were enriched in proteolytic enzymes. The band pattern of gelatinolytic enzymes (Fig. 1) released by cultures at increasing times after inoculation showed a consistent change and was correlated with achievement of stationary growth phase (constant $A_{600}$ ).

The enzymes were active in experiments in which incubation of post-electrophoresis gels proceeded in seawater instead of buffer containing $\mathrm{Ca}^{2+}$ and $\mathrm{Zn}^{2+}$, and generated the same band patterns (results not shown). The results indicated that the proteolytic processes reported in the present paper can occur in natural environments.

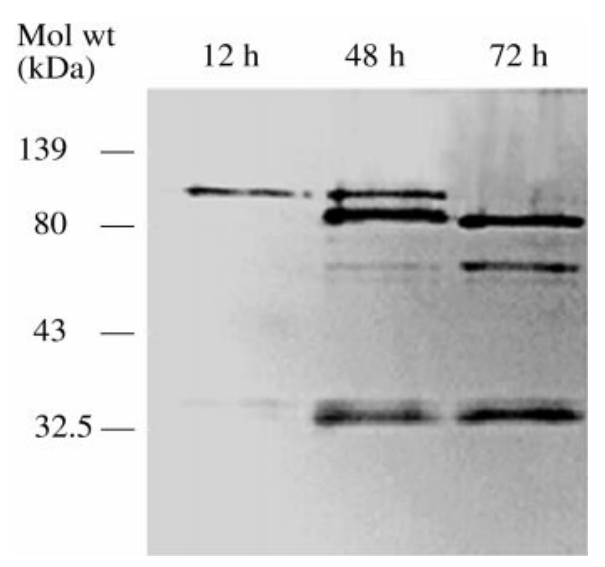

Fig. 1. Gelatin zymography of the 3 major families of extracellular proteases (by molecular weight) in different physiological states. Lane 1: early exponential phase (12 h old cultures). High molecular-weight activities are represented solely by the $103 \mathrm{kDa}$ band. The 75 to 69 and the 34 to $31 \mathrm{kDa}$ double bands are also present, at considerably lower intensity. Lane 2: exponential phase ( $48 \mathrm{~h}$ old cultures). Lane 3: onset of stationary phase ( $72 \mathrm{~h}$ old cultures). The $93 \mathrm{kDa}$ band is by far the predominant high molecular-weight enzyme activity. The image represents the negative of the gel. Approximate positions of the molecular-weight standards are indicated at the left of the gel, because both the standards and the substrate stain blue

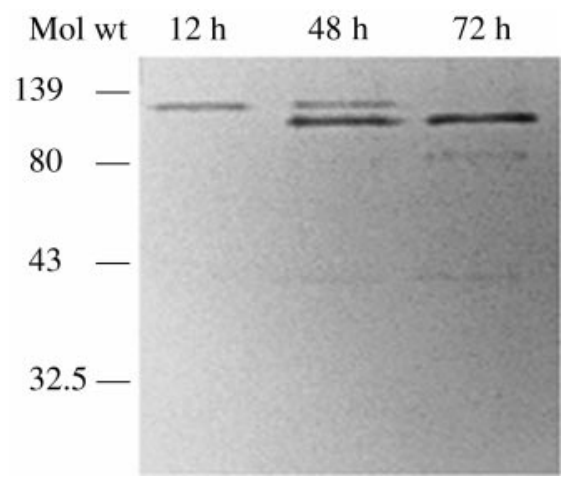

Fig. 2. Effect of EDTA on the enzyme activities of different molecular weights (for comparison, refer to Fig. 1 used as control). The response to the addition of $50 \mathrm{mM}$ (final concentration) EDTA in the sample (activation) buffer was dependent on the relative molecular weight of the extracellular enzyme activities. EDTA considerably diminished the proteolytic activities situated around 75 to $69 \mathrm{kDa}$ and inhibited the gelatinolytic activities that migrated to 34 to $31 \mathrm{kDa}$

\section{Classes of extracellular enzymes produced by Pseudoalteromonas atlantica}

The study showed that Pseudoalteromonas atlantica cells grown in batch cultures produced and exported a battery of proteases that readily degraded gelatin, but not casein or casamino acids. Among the inhibitors used to determine the classes of enzymes present, only EDTA and 1,10-phenanthroline showed an effect. Comparison of the banding patterns in Figs. 1 \& 2 shows that the enzymes demonstrated different susceptibility to inhibition. When EDTA was added prior to the sample buffer, and the gels were incubated in 50 $\mathrm{mM}$ Tris- $\mathrm{HCl}$ (with the omission of cations), the degradation of gelatin was totally inhibited. Inclusion of divalent cations in the incubation buffer during the incubation of the gels partly reversed the inhibitory effect. Also, the inhibitory effect was time-dependent. In the quantitative experiments, EDTA inhibited $85.57 \%$ of the total enzyme activity of cell-free supernatant samples (see Table 2, Fig. 3).

\section{Location of enzyme activities}

Proteolytic enzymes were detected in both fractions (cellular, and extracellular). As shown in Fig. 4, there are differences between the extracellular fractions and their cellular counterparts. In the 103 to $93 \mathrm{kDa}$ and the 34 to $31 \mathrm{kDa}$ range the extracellular extracts generated double bands of enzymatic, versus single bands in the cellular extracts. Around $75 \mathrm{kDa}$ the extracellular extracts displayed one band of gelatinolysis, while double bands (75 and $69 \mathrm{kDa}$ ) characterized the cellular extracts. 
Table 2. Fluorescent measurement of the inhibitory effect of EDTA on enzymatic activity in cell-free extracts. Data represent means \pm standard deviation $(n=4)$. cps $=$ counts per second

\begin{tabular}{|lcc|}
\hline Sample & Fluorescence increase ${ }^{\mathrm{a}}(\mathrm{cps})$ & $\%$ inhibition \\
\hline Control $^{\mathrm{b}}$ & $18793.6 \pm 895.94$ & 0 \\
Treatment $^{\mathrm{c}}$ & $2386.73 \pm 962.55$ & $85.57 \pm 7.37$ \\
& \\
& \\
${ }^{\mathrm{a}}$ Fluorescence (as cps) increase over $20 \mathrm{~h}$ incubations, at \\
room temperature, in the dark \\
${ }^{\mathrm{b} C o n t r o l: ~ c e l l-f r e e ~ e x t r a c t ~}+0.02 \mathrm{mg} \mathrm{ml}^{-1}$ gelatin Oregon \\
Green ${ }^{488}$ \\
${ }^{\mathrm{c}}$ Treatment: cell-free extract $+0.02 \mathrm{mg} \mathrm{ml}^{-1}$ gelatin Oregon \\
Green ${ }^{488}+2.5 \mathrm{mM}$ EDTA \\
\hline
\end{tabular}

Temporal stability of enzymes

To investigate whether post-export processing (proteolysis) of enzyme molecules was responsible for the shift toward lower molecular weights, we followed the fate of exponential phase enzymes over a period of 48 h. As shown in Fig. 5, in the absence of protein synthesis, the degradation of some of the high molecularweight bands resulted in the same sequence of patterns as seen in Fig. 1, which reflected the evolution of enzyme activities along a typical cell-growth curve. Enzymes were still active as long as $15 \mathrm{~d}$ after removal of cells and addition of chloramphenicol.

\section{Effect of pH on the enzymatic activities}

The extracellular enzymes produced by Pseudoalteromonas atlantica responded differently to $\mathrm{pH}$ variations, depending on their molecular weights (Fig. 6b). As a general observation, all enzymes were more sensitive to decreases, rather than increases in $\mathrm{pH}$. Acidic

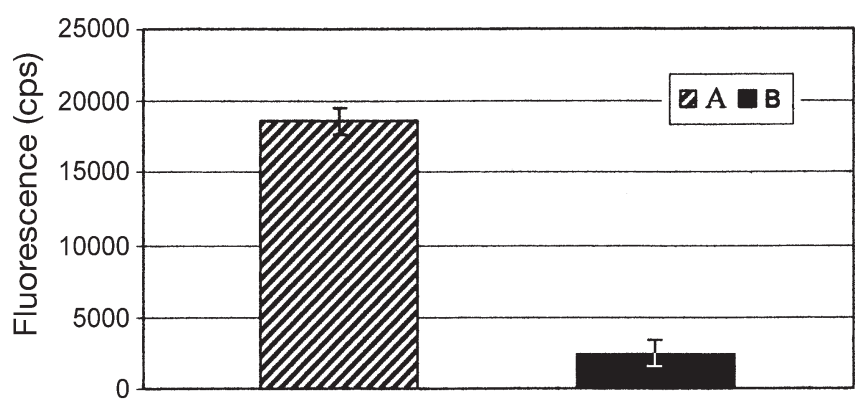

Fig. 3. Effect of EDTA on the proteolytic degradation of gelatin Oregon Green ${ }^{488}$. A: Enzyme activity, as fluorescence increase (Control); B: enzyme activity, as fluorescence increase, in the presence of $2.5 \mathrm{mM}$ EDTA (Treatment). $\mathrm{cps}=$ counts per second

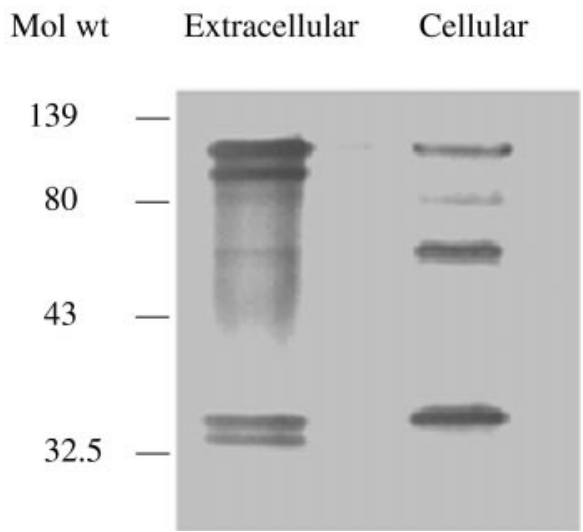

Fig. 4. Gelatin zymogram of enzyme activities separated in different cellular fractions. Lane 1: extracellular; Lane 2: pooled cellular compartments. Notice the absence of the 93 and $31 \mathrm{kDa}$ activities bands in the cellular versus extracellular fractions and the different intensities of the bands (considered in each individual lane)

$\mathrm{pH}$ decreased gelatin hydrolysis in all bands, although to various degrees (Fig. 6b). In contrast, increasing the $\mathrm{pH}$ to 10.4 stimulated the proteolytic activity, as determined by the intensity and area of the gelatin degradation. In view of the fact that natural seawater has $\mathrm{pH}$ values between 7.5 and 8.4 we decided to adjust the $\mathrm{pH}$ of the buffers used in the rest of experiments to 7.5 .

\section{DISCUSSION AND CONCLUSIONS}

The separation of enzymes by substrate incorporated polyacrylamide gel electrophoresis, followed by the activation of the enzymes in the appropriate buffer and the digestion of the substrate, is known as zymography (Granelli-Piperno \& Reich 1978). This technique was used in the present study to determine the presence of proteolytic enzymes in the compartments investigated (extracellular, and cellular), assign them to the class of metalloproteases, and determine the effects of various environmental parameters on the activity of individual enzymes.

In the arsenal of methods employed in enzyme studies, zymography holds some unique features that warranted its use in this study. The technique requires relatively small amounts of material (depending on the individual enzymes, sometimes less than nanograms of protein per band) and minimal manipulation of samples. The stained gels disclose the molecular weight of the enzymes, the number of different enzyme entities present in the sample, as well as the possibility of observing them individually. Substrates that generate fluorescent fragments, following enzymatic digestion, have been used effectively in quantitative studies, or for the purpose of comparisons (Hoppe et al. 1988, Tisl- 


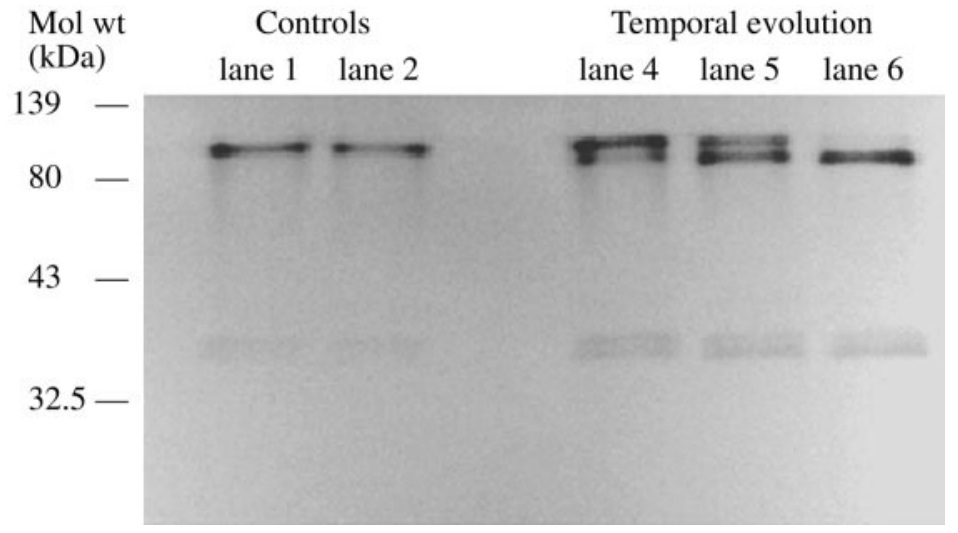

Fig. 5. Temporal stability of extracellular enzyme activities secreted by Pseudoalteromonas atlantica. Controls-lane 1: supernatant; lane 2: supernatant + chloramphenicol; Temporal evolution-lane 4: enzyme activities from supernatant (same treatment as lane 2) after $12 \mathrm{~h}_{\text {; lane }}$ 5: enzyme activities from supernatant (same treatment as lane 2) after $24 \mathrm{~h}$; lane 6 : enzyme activities from supernatant (same treatment as lane 2) after $48 \mathrm{~h}$. Note that the banding pattern follows the same evolution as shown in Fig. 1

pletely missed. Also, natural substrates for the enzymes secreted by wild-type bacteria are generally not known. Admittedly, the natural occurrence of gelatin (the chosen experimental substrate) in ocean water must be a rare event. Nevertheless, for the purpose of intraand inter-laboratory comparisons of the results generated by studies on such enzymes, a number of substrates had been adopted, e.g. gelatin and casein.

Aerobic heterotrophic bacteria depend on external organic compounds both for energy and carbon requirements (del Giorgio \& Cole 1998). In oceans, DOM covers a wide spectrum of origin, size, composition, chemical/ physical properties and nutritional value. Spatial and temporal microscale variability strongly influence the chemical identity, bioavailability and the relative proportions of DOM (Billen et al. 1980, Taylor et al. 1985, Romankevich \& Ljutsarev 1990, Lee \& Hen-

jar et al. 1990, Manafi et al. 1991, Hoppe 1993, Rattray et al. 1995, Seeram et al. 1997, Shibata et al. 1997, Arnosti 1998). Though highly sensitive, these methods will only display a global picture of the system, without providing information about the distinct enzymatic components. Different classes of proteases have different requirements for optimal activity. For these reasons fluorometric quantitation could not be used extensively in our study. In the present study, using zymography, it was determined that even enzymes belonging to the same class showed different levels of sensitivity to various environmental factors. A comparison of the location and intensities of the bands on a zymogram provided information specific for individual enzymes. The temperature/time conditions for the enzyme activity development were chosen such as to yield useful, consistent results in minimum time. Temperatures below $30^{\circ} \mathrm{C}$ required longer incubation times in order to obtain sufficiently clear bands, while at higher temperatures the bands of gelatinolysis typically lost the sharp contour due to enzymes diffusing through the gel.

One question can be raised: Was Pseudoalteromonas atlantica producing additional enzymes, irreversibly inhibited by the repeated use of SDS during the electrophoresis step? The present study did not intend to identify and characterize the full range of proteolytic enzymes that are, or may be produced by $P$. atlantica. There are inherent advantages and disadvantages related to the choice of a specific substrate, or technique. However, invariably certain enzyme classes will be com-

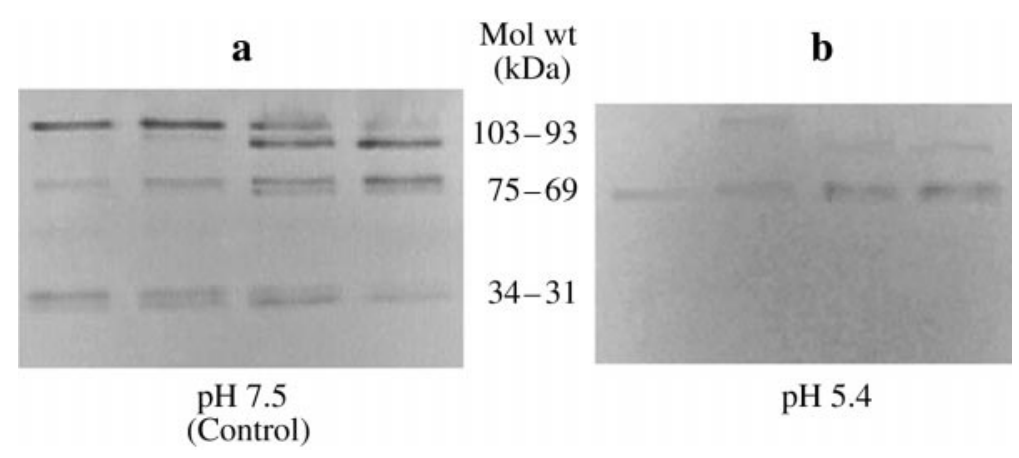

Fig. 6. Gelatin zymography of enzyme activities at (a) pH 7.4 and (b) pH 5.4. Note that in (b) the 75 to $69 \mathrm{kDa}$ bands of enzyme activity are the only ones readily observable, while the 103 to 93 and 34 to $31 \mathrm{kDa}$ bands were severely inhibited by the low $\mathrm{pH}$ value 
While the transport of nutrients and energy sources inside the microbial cells is important, a greater necessity is to produce and transport enzymes outside the cell where larger substrates are located. Therefore, it was expected that Pseudoalteromonas atlantica cells would export proteases, which could hydrolyze molecules for transport across the complex bacterial membranes.

Under the experimental conditions used in our study, Pseudoalteromonas atlantica bacteria produced and exported 3 major groups (by molecular weight) of gelatinolytic enzymes (see Fig. 1): 103-93, 75-69 and 34-31 kDa. The pattern of the extracellular proteolytic species produced by $P$. atlantica under long-term experimental conditions (in most experiments for 3 to $7 \mathrm{~d}$, but also for $15 \mathrm{~d}$ in one experiment) changed with time, favoring lower molecular-weight fragments.

In general, seawater has a relatively narrow chemical (ionic) composition and $\mathrm{pH}$ range. However, more significant variability may occur with regularity over small (e.g., mm to $\mu \mathrm{m}$ ) spatial scales. Since the enzymes under study belong to the class of metalloproteases we investigated the influence of $\mathrm{pH}$ and cation concentrations (specifically $\mathrm{Ca}^{2+}$ and $\mathrm{Zn}^{2+}$ ) on their proteolytic activity. The results showed that the enzymes respond differently to each of these environmental factors, and the magnitude of the response varies among the 3 major molecular-weight enzyme species.

Open ocean seawater is slightly alkaline, generally between 7.5 and $8.4 \mathrm{pH}$ units (Nybakken 1993). Under these conditions it was not surprising to find that an increase in the $\mathrm{pH}$ of the activity development buffer had very little effect on the activity (i.e., intensity of bands) of the enzymes. Most enzyme activities remained unchanged (if not slightly enhanced) up to $\mathrm{pH}$ 10.4. At acidic pHs, however, the extracellular enzymes of Pseudoalteromonas atlantica exhibited distinct differences in sensitivity. All bands of enzymatic activity showed some degree of inhibition when the $\mathrm{pH}$ of the activity development buffer was decreased under 7.5 units. However, the magnitude of the effect was not the same. As illustrated in Fig. 6, at pH 7.5 (gel a) the 103 to $93 \mathrm{kDa}$ bands of enzymatic activity are the most prominent. The very high molecular-weight (103 to $93 \mathrm{kDa}$ ) and the very low molecular-weight (34 to $31 \mathrm{kDa}$ ) enzymes are more susceptible to lower $\mathrm{pH}$ values than the 75 to $69 \mathrm{kDa}$ species (gel b). Even at pH 4.4 the 75 to $69 \mathrm{kDa}$ band(s) preserve(s) some gelatinolytic activity (results not shown due to the low contrast of the zymographic gels).

Individual susceptibility of enzymes to $\mathrm{pH}$ change may present an environmental advantage for the bacteria that synthesize such enzymes. While most ocean water is slightly alkaline and has a good buffering capacity, small microenvironments of acidity may be encountered where fermentation processes occur, such as in biofilm microenvironments or the phycosphere of a lysed microalgal cell. In the nutrient-limited open ocean environment such enzymatic flexibility represents a valuable adaptation.

Addition of EDTA to enzyme extracts prior the electrophoretic run, as well as in all subsequent buffers, resulted in total inhibition of digestion (i.e., enzyme activity) bands. However, if EDTA was added before electrophoresis, and divalent cations were provided in the subsequent steps, some enzyme species manifested partial recovery of enzymatic activity. Partial recovery of enzymatic activity reinforced the classification of the extracellular enzymes produced by Pseudoalteromonas atlantica as metalloproteases (Barrett 1994). The fluorometric measurement of the inhibitory effect of EDTA (at $2.5 \mathrm{mM}$ concentration) showed that residual enzymatic activity was possible. During the fluorometric quantitation of the inhibitory effect of EDTA, addition of $50 \mathrm{mM}$ EDTA to the samples caused partial quenching of fluorescence. Therefore, we had to decrease the concentration of EDTA to $2.5 \mathrm{mM}$. Also, fluorometry is 2 to 3 orders of magnitude more sensitive than staining techniques. Enzyme species (molecular-weight species) that were not inhibited by 2.5 mM EDTA, but remained undetected by gelatinincorporated electrophoresis, could be present and account for the residual enzymatic activity detected with the use of a more sensitive technique.

Comparison of the gels presented in Figs. 1 \& 3 indicated that higher molecular-weight enzymes were less affected by the initial addition of EDTA, as long as cations were provided in the following steps. Divalent cations participate in the correct folding of macromolecules, and in the present situation they may be responsible for stabilizing the catalytic sites, recognition/ binding sites, and/or the overall 3-dimensional structure of the enzymes. Of course, until primary and tertiary structures of bacterial enzymes are available, the stability of higher molecular-weight versus lower molecular-weight molecules remains open to interpretation.

Pseudoalteromonas atlantica were cultivated in nutrient-enriched, sterile-filtered Gulf Stream water, at 25 ppt salinity. However, traditionally, enzyme activity is evaluated by substrate degradation in incubation buffer, supplemented with cations. We considered it essential to examine whether natural seawater can offer the range of conditions ( $\mathrm{pH}$, divalent cations) favorable for the activity of the enzymes under study.

It is interesting to note that the initial size of the enzymes dictated the order in which the lower molecular fragments were generated. The first double bands (34 and $31 \mathrm{kDa}$ ) of enzymatic activity appeared in the medium as early as $12 \mathrm{~h}$ after inoculation and became 
the dominant species at longer incubation times. The lower molecular-weight members of the double bands are probably the result of the removal of a molecular fragment that obstructs the catalytic site. This has been previously documented as a common activation step of some mammalian proteases (Nagase et al. 1990, Bläser et al. 1991). In order to avoid unspecific degradation of intracellular proteins, proteases are often synthesized with an additional segment that obstructs the catalytic site. This latent form (called either proenzyme, or zymogen) displays up to $60 \%$ of the activity of the fully active molecule (Woessner 1995). Outside the cells, the fragment is cleaved off and full activity is achieved.

We recognized the possibility that during handling, or due to cellular death and loss of membrane integrity, some intracellular enzymes could leak into the medium. Fig. 4 represents a typical comparison of extracellular versus cellular enzyme species. Although the enzyme activities were localized at the same molecular weights, the relative intensities on each lane and between the lanes suggested that no significant leakage of cellular enzymes occurred. First, the enzymes around 75 to $69 \mathrm{kDa}$ were present as double bands only in the cellular fraction (lane 3 vs lane 1). Second, 103 to $93 \mathrm{kDa}$ double bands were considerably more intense relative to the rest of the bands on the same lane and only present as a pair in the extracellular fraction (lane 1).

In the cellular environment, molecules are exposed to fewer interactions that can result in partial degradation. The presence of active forms of enzyme in the periplasm and cytoplasm has the potential for accidental cleavage of other proteins, not meant to serve as substrates. On the other hand, the efficiency of complete degradation of larger molecules would increase if hydrolysis of oligomers could occur inside bacterial cells. Once inside the outer membrane, oligomeric fragments are safe from diffusional loss and/or uptake by competing microorganisms. Since in our study the cells and supernatant were processed at the same time, stored and run under the same conditions and using the same reagents, the possibility of artifact was considered negligible. Furthermore, enzyme banding patterns were consistent in similar samples generated across different experiments.

The gradual accumulation of the lower molecularweight species prompted the investigation of the events that followed the transport of proteolytic enzymes outside the cells. A change in the gelatinolysis pattern was observed during the course of the initial experiments that followed the fate of enzymatic activities along different physiological states. As shown in Fig. 5, supernatants in which protein synthesis had been inhibited displayed the same sequence of banding patterns as observed in Fig. 1. The 2 controls (lanes 1 and 2) gen- erated the same bands of gelatinolysis, demonstrating that chloramphenicol had no effect on either the molecular weight (structure), or the activity of the secreted enzymes. Also, the constant $A_{600}$ value for $72 \mathrm{~h}$ after the experiment was performed indicated that there was no bacterial growth continuing and affecting the enzymatic composition of the samples. It was concluded, therefore, that the extracellular proteolysis accounted for the molecular-weight change. Comparing Figs. 1 \& 5, we suggest the following sequence of events may occur: While cells were in exponential phase, enzymes were produced, exported and gradually hydrolyzed. When the degradable nutrient levels decrease the synthesis of new enzyme molecules (103, $75,34 \mathrm{kDa}$ ) is discontinued, or at least decreased below the detection limits of the substrate incorporated electrophoresis. Nevertheless, the previously externalized enzymes (in the form of the 93,69, and $31 \mathrm{kDa}$ species) remained active in the medium for at least $15 \mathrm{~d}$ (although showing a decreasing activity).

The present study showed that the metalloproteases produced by Pseudoalteromonas atlantica displayed different susceptibility to variations of the environmental factors considered. This should create a considerable advantage for $P$. atlantica response to changing nutritional conditions, and allow the bacteria to remain enzymatically active under a range of oceanic conditions. Extensive temporal stability of some extracellular enzymes may explain the rapid response of microorganisms to the sporadic nutrient fluctuations that characterizes most marine environments. Cell-free enzymes in seawater have been previously reported (Kim \& ZoBell 1974, Hollibaugh \& Azam 1983). Pre-existing active enzymes, in the vicinity of bacteria, could generate amino acids and energy sources that would enable the cells to restart their metabolism in short order. It could be argued, however, that active enzymes would not benefit the exporting cells for long. While inside the cell, molecules are influenced by physical parameters $(\mathrm{pH}$, ionic strength) that reflect the cell's physiology. The external environment is to a large extent independent from cellular control. The chemical integrity, hence biological activity, of extracellular enzymes could be adversely affected. Furthermore, diffusional losses and micro-currents, waves or temperature gradients would ultimately disperse the extracellular enzymes. Exopolymer capsules and biofilm microenvironments can potentially localize and protect the enzymes as well as substrates, extending their usefulness for the bacteria (Pedrós-Alió \& Brock 1983).

Acknowledgements. This work was partly supported by NSF grant OCE 95-23712, ONR grant N 001-497-10024, and conducted in partial fulfillment of dissertation research for M.H. 


\section{LITERATURE CITED}

Albertson NH, Nyström T, Kjelleberg S (1990) Exoprotease activity of two marine bacteria during starvation. Appl Environ Microbiol 56(1):218-223

Alldredge AL, Cohen Y (1987) Can microscale chemical patches persist in the sea? Microelectrode study of marine snow, fecal pellets. Science 235:688-691

Amon RMW, Benner R (1994) Rapid cycling of high-molecular weight dissolved organic matter in the ocean. Nature 369: $549-552$

Arnosti C (1998) Rapid potential rates of extracellular enzymatic hydrolysis in Arctic sediments. Limnol Oceanogr 43: 315-324

Azam F (1998) Microbial control of ocean carbon flux: the plot thickens. Science 280:694-696

Azam F, Ammerman JW (1984) Cycling of organic matter by bacterioplankton in pelagic marine ecosystems: microenvironmental considerations. In: Fasham MJR (ed) Flows of energy and materials in marine ecosystems. Plenum Press, New York, p 345-360

Barrett AJ (1994) Classification of peptidases. In: Barrett AJ (ed) Methods in enzymology proteolytic enzymes: serine and cysteine peptidases. Academic Press, San Diego, CA, p 1-15

Billen G, Joiris C, Wijnant J, Gillain G (1980) Concentration and microbiological utilization of small organic molecules in the Scheldt estuary, the Belgian coastal zone of the North Sea and the English Channel. Estuar Coast Mar Sci 11:279-294

Blackburn N, Fenchel T, Mitchell J (1998) Microscale nutrient patches in planktonic habitats shown by chemotactic bacteria. Science 282:2254-2256

Bläser J, Knäuper V, Osthues A, Reinke H, Tschesche H (1991) Mercurial activation of human polymorphonuclear leukocyte procollagenase. Eur J Biochem 202:1223-1230

Cascieri T, Mallette MF (1976) Peptide utilization by Pseudomonas putida and Pseudomonas maltophilia. J Gen Microbiol 92:283-295

Chróst RJ (1990) Microbial ectoenzymes in aquatic environments. In: Overbeck J, Chróst RJ (eds) Aquatic microbial ecology-biochemical and molecular approaches. SpringerVerlag, New York, p 47-78

Chróst RJ (1991) Environmental control of the synthesis and activity of aquatic microbial ectoenzymes. In: Chróst RJ (ed) Microbial enzymes in aquatic environments. SpringerVerlag, Berlin, p 29-59

Corpe WA (1970) An acidic polysaccharide produced by a primary film-forming marine bacterium. Dev Ind Microbiol 11:402-412

Dawes EA (1985) Starvation, survival and energy reserves. In: Fletcher M, Floodgate GD (eds) Bacteria in their natural environments. Academic Press, San Diego, CA, p 43-80

Decho AW, Lopez GR (1993) Exopolymer microenvironments of microbial flora: multiple and interactive effects on trophic relationships. Limnol Oceanogr 38:1633-1645

del Giorgio PA, Cole JJ (1998) Bacterial growth efficiency in natural aquatic systems. Annu Rev Ecol Syst 29:503-541

Engasser JM, Horvath C (1974a) Inhibition of bound enzymes. I. Antienergistic interaction of chemical and diffusional inhibition. Biochemistry 13:3845-3849

Engasser JM, Horvath C (1974b) Inhibition of bound enzymes. II. Characterization of product inhibition and accumulation. Biochemistry 13:3849-3854

Gilvarg C, Katchalski E (1965) Peptide utilization in Escherichia coli. J Biol Chem 240:3093-3098

Granelli-Piperno A, Reich A (1978) A study of proteases and protease-inhibitor complexes in biological fluids. J Exp Med 148:223-234

Herndl GJ (1988) Ecology of amorphous aggregations (marine snow) in the Northern Adriatic Sea. II. Microbial density and activity in marine snow and its implication to overall pelagic processes. Mar Ecol Prog Ser 48:265-275

Hollibaugh JT, Azam F (1983) Microbial degradation of dissolved proteins in seawater. Limnol Oceanogr 28: $1104-1116$

Hoppe HG (1993) Use of fluorogenic substrates for extracellular enzyme activity (EEA) measurement of bacteria. In: Kemp PF, Sherr BF, Sherr EB, Cole JJ (eds) Handbook of methods in aquatic microbial ecology. Lewis Publishers, Boca Raton, FL, p 423-431

Hoppe HG, Kim SJ, Gocke K (1988) Microbial decomposition in aquatic environments; combined process of extracellular enzyme activity and substrate uptake. Appl Environ Microbiol 54:784-790

Kim J, ZoBell CE (1974) Occurrence and activities of cell-free enzymes in oceanic environments. In: Colwell RR, Morita RY (eds) Effect of the ocean environment on microbial activities. University Park Press, Baltimore, MD, p 368-385

Kjelleberg S, Humphrey B, Marshall K (1983) Initial phases of starvation and activity of bacteria at surfaces. Appl Environ Microbiol 46:978-984

Krembs C, Juhl AR, Azam F (1998) Nanoscale patchiness of bacteria in lake water studied with the spatial information preservation method. Limnol Oceanogr 43:307-314

Laemmli UK (1970) Cleavage of structural proteins during the assembly of the head of bacteriophage T4. Nature 227: $680-685$

Lee C, Henricks SM (1993) How the nature of dissolved organic matter might affect the analysis of dissolved organic carbon. Mar Chem 41:105-120

Manafi M, Kneifel W, Bascomb S (1991) Fluorogenic and chromatogenic substrates used in bacterial diagnostics. Microbiol Rev 55:335-348

Morita RY (1985) Starvation and miniaturisation of heterotrophs, with special emphasis on maintenance of the starved viable state. In: Fletcher M, Floodgate GD (eds) Bacteria in their natural environments. Academic Press, San Diego, CA, p 111-130

Nagase H, Enghild JJ, Suzuki K, Salvesen G (1990) Stepwise activation mechanisms of the precursor of matrix metalloproteinase and (4-aminophenyl) mercuric acetate. Biochemistry 29:5783-5789

Nybakken JW (1993) Introduction to the marine environment. In: Davies G (ed) Marine biology: an ecological approach, 3rd edn. Harper Collins College Publishers, New York, p 1-6

Payne JW (1980) Transport and utilization of peptides by bacteria. In: Payne JW (ed) Microorganisms and nitrogen sources. John Wiley and Sons, Chichester, p 212-256

Payne JW, Gilvarg C (1968) Size restriction on peptide utilization in Escherichia coli. J Biol Chem 243:6291-6299

Pedrós-Alió C, Brock TD (1983) The importance of attachment to particles for planktonic bacteria. Arch Hydrobiol 98:354-379

Rattray FP, Bockelmann W, Fox PF (1995) Purification and characterization of an extracellular proteinase from Brevibacterium linens ATCC 9174. Appl Environ Microbiol 61:3454-3456

Romankevich EA, Ljutsarev SV (1990) Dissolved organic carbon in the ocean. Mar Chem 30:161-178

Seeram SS, Hiraga K, Saji A, Tashiro M, Oda K (1997) Identification of reactive site of a proteinaceous metalloproteinase inhibitor from Streptomyces nigrescens TK-23. 
J Biochem 121:1088-1095

Sepers ABJ (1997) The utilization of dissolved organic compounds in aquatic environments. Hydrobiologia 52:39-54

Shibata M, Takahashi S, Sato R, Oda K (1997) A novel metalloproteinase, Amelysin, from a marine bacterium, Alteromonas sp. no. 3696: purification and characterization. Biosci Biotechnol Biochem 61:710-715

Singleton P, Sainsbury D (1987) Dictionary of microbiology and molecular biology, 2nd edn. John Wiley and Sons, New York, p 623

Skoog A, Biddandra B, Benner R (1999) Bacterial utilization of dissolved glucose in the upper water column of the Gulf of Mexico. Limnol Oceanogr 44:1625-1633

Smith DC, Simon M, Alldredge AL, Azam F (1992) Intense hydrolytic enzyme activity on marine aggregates and im-

Editorial responsibility: James Hollibaugh,

Athens, Georgia, USA plications for rapid particle dissolution. Nature 359:139-142

Taylor GT, Iturriaga R, Sullivan CW (1985) Interaction of bactivorous grazers and heterotrophic bacteria with dissolved organic matter. Mar Ecol Prog Series 23:129-141

Tisljar U, Knoght CG, Barrett AJ (1990) An alternative quenched fluorescence substrate for $\mathrm{Pz}$ - peptidase. Anal Biochem 186:112-115

Wetzel RG (1991) Extracellular enzymatic interactions: storage, redistribution, and interspecific communication. In: Chróst RJ (ed) Microbial enzymes in aquatic environments. Springer-Verlag, Berlin, p 6-28

Woessner J Jr (1995) Quantification of matrix metalloproteinases in tissue samples. In: Barrett AJ (ed) Methods in enzymology-proteolytic enzymes: aspartic and metallopeptidases. Academic Press, San Diego, CA, p 510-528

Submitted: January 31, 2000; Accepted: June 28, 2000

Proofs received from author(s): November 14, 2000 